\title{
Acute polyarthritis following the use of Corynebacterium parvum vaccine (Copar- vax) for malignant pleural effusion
}

\author{
A. M. L. LEVER* \\ B.Sc., M.R.C.P.
}

J. FORSYTHE
M.B., B.S.

\author{
P. OXFORD \\ M.B., B.S.
}

Hexham General Hospital, Hexham, Northumberland NE46 1QJ

\begin{abstract}
Summary
A 77-year-old man with a malignant pleural effusion was treated by aspiration of fluid and injection of Corynbacterium parvum vaccine for pleurodesis. Within $24 \mathrm{hr}$ he had developed a temperature and a neutropenia followed by an acute crippling polyarthritis of his hands and wrists which subsequently responded to oral steroids and non-steroidal antiinfiammatory drugs.
\end{abstract}

KEY WORDS: Coparvax, polyarthritis, malignant effusion.

\section{Introduction}

Rapid reaccumulation of fluid in malignant pleural effusion is a well-recognized clinical problem for which there is no completely successful therapy. Corynebacterium parvum vaccine (Coparvax) has been shown to be a useful agent for malignant effusions, its effect being thought to be a combination of chemical irritation combined with potent immunologic stimulation. The side effects reported to date have been minimal (Millar, Hunter and Horne, 1980).

\section{Case report}

A 77-year-old man presented with a 5-week history of progressive dyspnoea and was found to have a large right-sided pleural effusion. Physical examination revealed a pleural effusion but nothing else of note. Aspiration produced 1 litre of straw-coloured fluid, protein content $35 \mathrm{~g} /$ litre, glucose $4.1 \mathrm{mmol} /$ litre. Microscopy and culture for usual pathogens and acid fast bacilli were negative. Cytology of the fluid showed cells consistent with origin from squamous carcinoma. In the meantime, 2 further litres of fluid

\footnotetext{
*Present address: Division of Immunological Medicine, Clinical Research Centre, Watford Road, Harrow, Middlesex.
}

had been removed and pleural biopsy was performed suggestive also of malignancy. Bronchoscopy revealed no endobronchial lesion. A further aspiration of fluid was performed and $7 \mathrm{mg}$ of Coparvax injected into the pleural space. The day following this the patient was found have a temperature of $38^{\circ} \mathrm{C}$ and over the next 3 days he developed a severe polyarthritis affecting both wrists, metacarpophalangeal joints and proximal interphalangeal joints. He became totally unable to use his hands and unwell with nausea, anorexia and rigors. X-ray of his hands showed soft tissue swelling and degenerative changes but no evidence of erosive arthropathy or hypertrophic pulmonary osteoarthropathy.

A neutropenia (16\% of a total white cell count of $6.6 \times 10^{9} /$ litre) was noted. Rheumatoid factor, antinuclear factor and other autoantibody tests were negative. Viral titres to influenza, adenovirus, respiratory syncytial virus, mumps, mycoplasma, EpsteinBarr virus and Coxsackie B1-B6 were all negative. Circulating immune complexes were not sought.

There was no evidence of focal or systemic sepsis and this was presumed to be an acute reaction to the Coparvax. Treatment with indomethacin and prednisone, $30 \mathrm{mg}$ per day, was commenced following which the symptoms of neutropaenia and synovitis disappeared. At follow-up, there was no evidence of soft tissue swelling at any joint and there was a full range of movement. He was subsequently treated with chemotherapy which he tolerated well.

\section{Discussion}

Coparvax has been shown to inhibit tumour growth in animals (Halpern, Biozzi and Stiffel, 1966), and to stimulate macrophage function and phagocytosis and decrease the proliferative response of lymphocytes to common antigens (phytohaemagglutinin, pokeweed mitogen, concanavalin A) (Hilal et al., 1981). 
Side effects described in the past have been maximal when the intravenous route has been used for its administration. These include nausea, vomiting, pyrexia, hypertension, diarrhoea, chest pain, peripheral cyanosis, headaches and transient elevation of liver enzymes (Gall et al., 1978). Polyarthritis has not been previously described, but a large dose of bacterial antigen such as this might be suspected to be capable of producing an immune complexmediated arthritis, or, with its wide ranging immunological effects, precipitate a polyarthritis in a predisposed individual. Indeed, it has been suggested that Coparvax may be contraindicated in a patient with an auto-immune predisposition (Dorr and Fritz, 1980).

With increasing use of Coparvax for malignant effusion, it is important to be aware of this possible adverse effect and its eminently treatable nature.
Confusion with hypertrophic pulmonary osteo变 thropathy is also a possibility.

\section{References}

DORR, R.T. \& FRITZ, W.L. (1980) In: Cancer Chemotherepp Handbook, p. 336. Henry Kimpton, London.

Gall, S.A., Disali, P.J., Schmidt, H., Mittelstaedt, $\overline{\text { q. }}$ Newman, P. \& CREASMAN, W. (1978) Toxicity manifestatigns following intravenous Corynebacterium parvum administratiof to patients with ovarian and cervical carcinoma. American Journgfor Obstetrics and Gynecology, 132, 555.

Halpern, B.M., Biozzi, G., Stiffel, C. \& Mouton, D. (1966) Inhibition of tumour growth by administration of killed $C$ parvum. Nature, 212, 853.

Hilal, E.Y., Pinsky, C.M., HiRshaut, Y., Wanebo, H.J., Hans? J.A., Braun, D.W., Fortner, J.G. \& Oettgen, H.F. (1981) Surgical adjuvant therapy of malignant melanoma with Cokpe bacterium parvum. Cancer, 48, 245.

MillaR, J.W., HUNTER, A.M. \& HoRNe, N.W. (1980) Intrapleina immunotherapy with Corynebacterium parvum in recurrent mâfig nant pleural effusions. Thorax, 35, 856 .

(Accepted 11 January 1983) 